\title{
Особливості виконання передач м'яча кращими командами Прем'єр- та Першої ліги України 3 футболу
}

\author{
Анатолій Абдула
}

Харківська державна академія фізичної культури, Харків, Україна

Мета: визначити показники виконання передач м'яча у футболі команд різної кваліфікації.

Матеріал і методи: реєстрація передач м'яча здійснювалася на прикладі кращих команд Прем'єр-ліги: «Динамо» Київ, «Шахтар» Донецьк, «Зоря» Луганськ та лідерів Першої ліги України: «Верес» Рівне, «Чорноморець» Одеса, «Металіст 1925» Харків сезону 2020/2021 р. Всього було проаналізовано 90 футбольних матчів. Для вирішення поставлених задач в роботі застосовувалися такі методи дослідження: аналіз науково-методичної літератури, реєстрація передач м'яча під час гри, методи математичної статистики.

Результати: у статті представлено дані щодо виконання передач м'яча кращими командами Прем'єр- та Першої ліги України з футболу. Проведений аналіз ефективності загальної кількості передач м'яча, передач вперед, довгих передач, передач в останню третину поля, передач в розріз та визначався темп гри кожної з команд. Встановлені відмінності використання передач м'яча кращими командами Прем'єр-ліги: «Динамо» Київ, “Шахтар» Донецьк, «Зоря» Луганськ та лідерів Першої ліги України: «Верес» Рівне, «Чорноморець» Одеса, «Металіст 1925» Харків сезону 2020/2021 p.

Висновки: дані дослідження свідчать про відмінності використання передач м'яча командами різної кваліфікації у чемпіонаті та першості України з футболу сезону 2020/2021 р. Так, відзначається, що у команд більш високого рівня кращі показники загальної кількості передач та передач м'яча в розріз, а кількість довгих передач значно нижча.

Ключові слова: передачі м'яча, тактика, ефективність, темп гри.

\section{Вступ}

Футбол - динамічна гра, яка потребує великої концентрації ігрових дій гравців протягом всього матчу. Важливу роль під час гри має контроль м'яча, що дозволяє команді змінювати темп та ритм футбольного матчу $[3,8,12]$. Передачі м'яча - один з головних компонентів контролю м'яча у футболі, який об'єднує індивідуальну та групову тактику гри.

Крім цього Голомазов С., Чирва Б., Лисенчук Г., Шамардін В.М. $[1,2,7]$ вважають, що від ефективності передач у футболі досить часто залежить кінцевий результат футбольного матчу.

У свою чергу Перевозник В., Перцухов А. $[4,5,6]$ стверджують, що рівень команди в першу чергу залежить від кількісних та якісних показників передач в один та два дотики.

Для оцінки ефективності передач м'яча у футболі розрізняють $[7,9,11]$ : передачі по дистанції: короткі (510 м), середні (10-25 м), довгі (більше 25 м); передачі за напрямом: назад, поперек, вперед; ключові передачі: в останню третину поля (передача в 35 метрову зону від лінії воріт суперника), передачі в розріз; темп гри (кількість передач на хвилину володіння м'ячем) [3].

Мета дослідження - визначити показники виконання передач м'яча у футболі команд різної кваліфікації.

\section{Матеріал і методи дослідження}

Для вирішення поставлених завдань в роботі застосовувалися такі методи дослідження: аналіз науково-методичної літератури, реєстрація передач м'яча під час гри, методи математичної статистики. Реєстрація передач м'яча здійснювалася завдяки запису різних видів передач в спеціально розроблену таблицю під час гри кращих команд Прем'єр-ліги: «Динамо» Київ, «Шахтар» Донецьк, «Зоря» Луганськ та лідерів Першої ліги України: «Верес» Рівне, «Чорноморець» Одеса, «Металіст 1925» Харків сезону 2020/2021 р. Так реєструвалися наступні показники: передачі вперед, довгі передачі, передачі в останню третину поля, передачі в розріз. Також було визначено темп гри кожної з трьох кращих команд Прем'єр- та Першої ліги України. 
Таблиця 1

Показники виконання передач м'яча кращих команд Прем'єр-ліги України з футболу сезону 2020/2021

\begin{tabular}{|c|c|c|c|c|c|c|}
\hline Команди & $\begin{array}{l}\text { Всього } \\
\text { передачі, } \\
\text { к-ть разів }\end{array}$ & $\begin{array}{l}\text { Передачі } \\
\text { вперед, } \\
\text { к-ть разів }\end{array}$ & $\begin{array}{l}\text { Довгі } \\
\text { передачі, } \\
\text { к-ть разів }\end{array}$ & $\begin{array}{l}\text { Передачі в } \\
\text { останню } \\
\text { третину, } \\
\text { к-ть разів }\end{array}$ & $\begin{array}{l}\text { Передачі } \\
\text { в розріз, } \\
\text { к-ть разів }\end{array}$ & $\begin{array}{l}\text { Темп } \\
\text { гри, } \\
\text { передач/ } \\
\text { хв }\end{array}$ \\
\hline $\begin{array}{c}\text { «инамо» } \\
\text { Київ } \\
\text { (n 15) }\end{array}$ & $488,8 \pm 20,3$ & $140,8 \pm 18,7$ & $41,2 \pm 3,7$ & $58,9 \pm 3,8$ & $8,8 \pm 0,2$ & $17,3 \pm 0,4$ \\
\hline $\begin{array}{c}\text { «Шахтар» } \\
\text { Донецьк } \\
\text { (п 15) }\end{array}$ & $577,9 \pm 27,3$ & $155,6 \pm 19,8$ & $37,8 \pm 2,9$ & $70,1 \pm 4,6$ & $10,8 \pm 0,3$ & $17,3 \pm 0,4$ \\
\hline $\begin{array}{c}\text { «Зряя» } \\
\text { Луганськ } \\
\text { (п 15) }\end{array}$ & $397,2 \pm 43,4$ & $138,7 \pm 19,3$ & $47,8 \pm 4,3$ & $53,7 \pm 4,3$ & $8,0 \pm 0,2$ & $16,1 \pm 0,7$ \\
\hline
\end{tabular}

\section{Результати дослідження}

У таблиці 1 представлено показники виконання передач м'яча під час гри кращими командами Прем'єр ліги України сезону 2020/2021 р. 3 таблиці видно, що команда «Зоря» Луганськ має перевагу в кількості довгихпередачза гру 47,8 44,3 раз, що пояснюється рівнем підготовленості та тактичними діями гравців команди. Команда «Шахтар» Донецьк переважає «Динамо» та «Зорю» за усіма показниками, однак, темп гри у «Динамо» і «Шахтаря» однаковий - 17,3 0,4 передач за хвилину володіння м'ячем.
Показники ефективності (\%) виконання передач кращими командами Прем'єр-ліги представлені на рис.1. Так, команда «Шахтар» переважає «Динамо» та «Зорю» за усіма показниками, тільки передачі в розріз мають такі ж показники, як і у луганчан - 33 \%. Значно нижчі показники ефективності передач м'яча «Зорі» при виконанні в останню третину поля суперника та становить 69 \%, на відміну від «Динамо» - 75 \% та 83 \% у «Шахтаря».

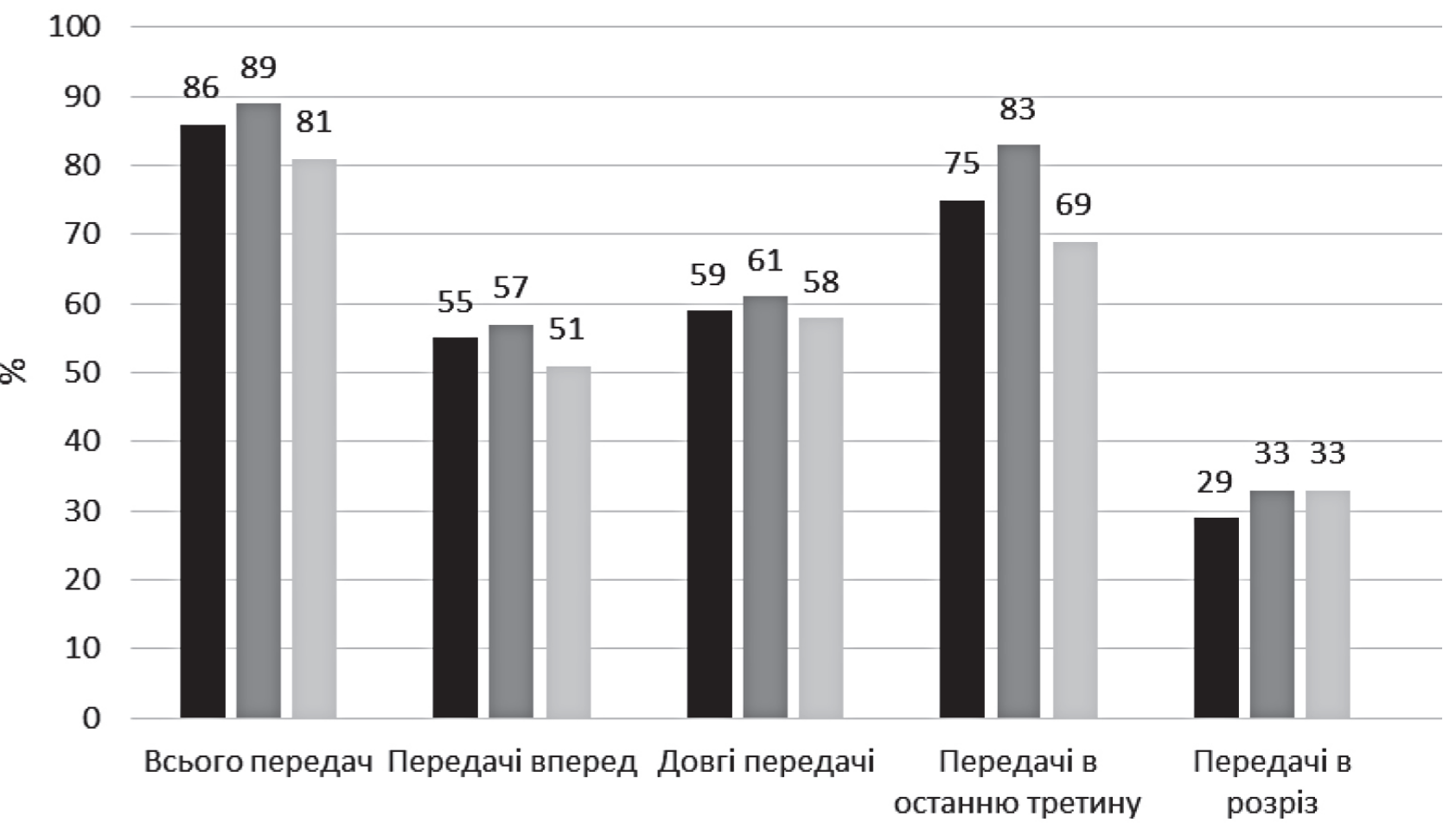

Динамо ш Шахтар Воря

Рис. 1. Ефективність виконання передач м'яча кращих команд Прем'єр- ліги України сезону 2020/2021 р. 


\section{Таблиця 2}

Показники виконання передач м'яча кращими командами Першої ліги України 3 футболу сезону 2020/2021

\begin{tabular}{|l|l|l|l|l|l|l|}
\hline Команди & $\begin{array}{l}\text { Всього } \\
\text { передачі, } \\
\text { к-ть разів }\end{array}$ & $\begin{array}{l}\text { Передачі } \\
\text { вперед, } \\
\text { к-ть разів }\end{array}$ & $\begin{array}{l}\text { Довгі } \\
\text { передачі, } \\
\text { к-ть разів }\end{array}$ & $\begin{array}{l}\text { Передачі } \\
\text { останню } \\
\text { третину, } \\
\text { к-ть разів }\end{array}$ & $\begin{array}{l}\text { Передачі } \\
\text { в розріз, } \\
\text { к-ть разів }\end{array}$ & $\begin{array}{l}\text { Темп } \\
\text { гри, } \\
\text { передач/ } \\
\text { хв }\end{array}$ \\
\hline $\begin{array}{l}\text { «Верес» } \\
\text { Рівне } \\
\text { (n 15) }\end{array}$ & $334,8 \pm 38,6$ & $130,1 \pm 12,8$ & $60,6 \pm 4,3$ & $54,2 \pm 7,3$ & $6,6 \pm 0,2$ & $15,4 \pm 0,5$ \\
\hline $\begin{array}{l}\text { «Чорномо } \\
\text {-рець» } \\
\begin{array}{l}\text { Одеса } \\
\text { (п 15) }\end{array}\end{array} 417,1 \pm 28,7$ & $146,1 \pm 21,3$ & $50,0 \pm 3,7$ & $60,5 \pm 5,4$ & $9,8 \pm 0,3$ & $16,6 \pm 0,3$ \\
\hline $\begin{array}{l}\text { «Металіст } \\
\text { 1925» } \\
\text { Харків } \\
\text { (п 15) }\end{array}$ & $436,2 \pm 22,7$ & $147,7 \pm 15,7$ & $50,0 \pm 3,1$ & $57,8 \pm 4,7$ & $8,6 \pm 0,2$ & $16,1 \pm 0,4$ \\
\hline
\end{tabular}

Аналізуючи дані таблиці 2, можна дійти висновку, що команда «Металіст 1925» Харків переважає команди «Верес» та «Чорноморець» в показниках загальної кількості

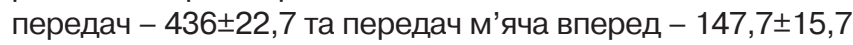
передач за гру. У команди «Верес» Рівне кращі показники в кількості довгих передач - 60,6士4,3. «Чорноморець» Одеса має кращі показники в кількості ключових передач: в остан-

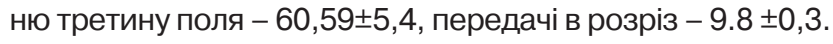

Показники ефективності виконання передач (\%) кращими командами Першої ліги представлені на рис.2. Так, команда «Металіст 1925» переважає «Верес» та «Чорноморець» за загальною ефективністю виконання передач (83\%), у команди «Чорноморець» вищі показники при виконанні довгих передач (67\%) та передач в останню третину поля (67\%), а у «Вереса» - передачі м'яча в розріз (30\%) .

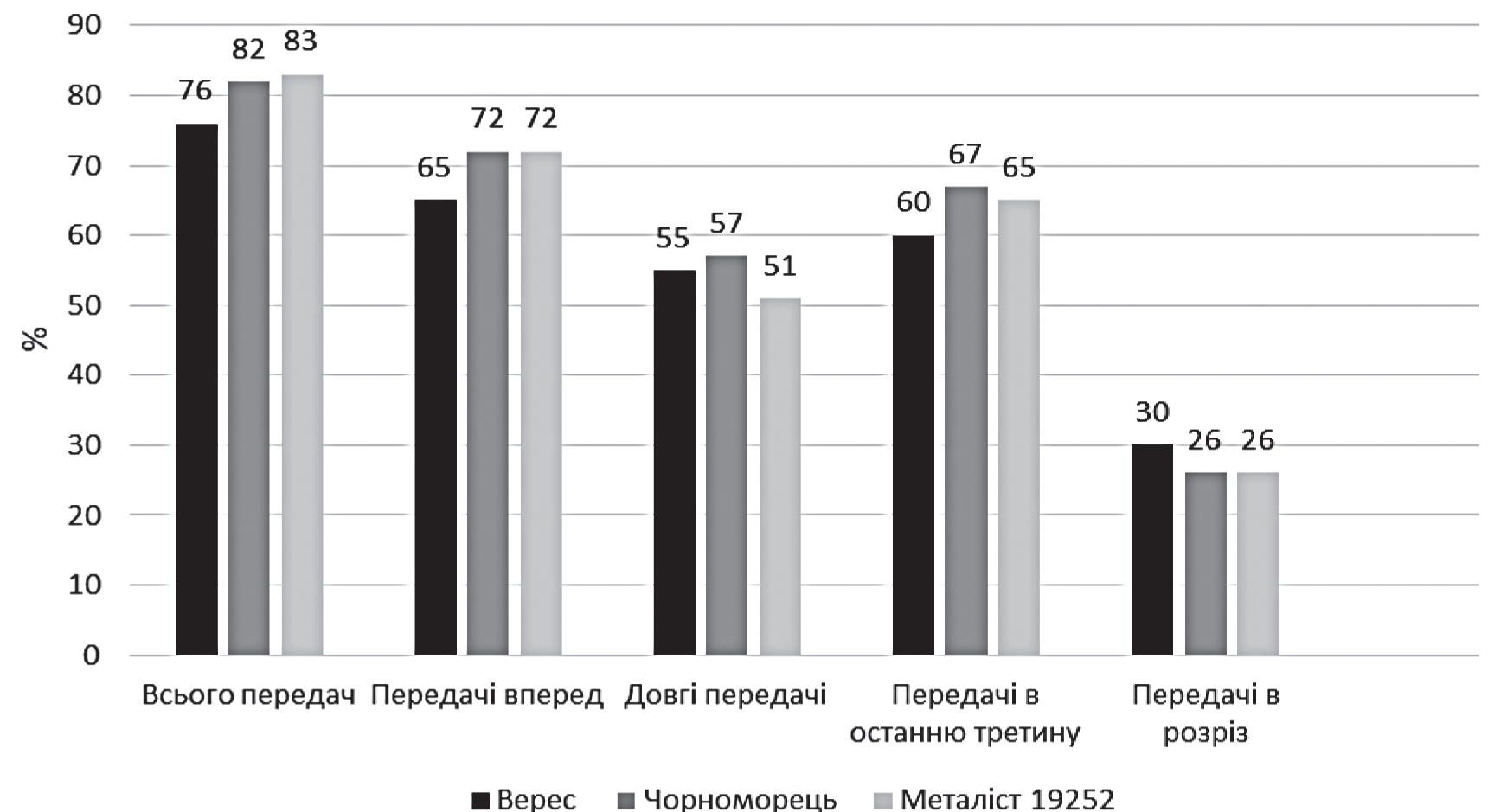

Рис. 2. Ефективність виконання передач м'яча кращих команд Першої ліги України сезону 2020/2021 
Таблиця 3

Показники виконання передач м'яча кращими командами Прем'єр- та Першої ліги України 3 футболу сезону 2020/2021

\begin{tabular}{|c|c|c|c|c|}
\hline Види передач & $\begin{array}{l}\text { Кращі команди } \\
\text { Прем'єр-ліги } \\
\text { України (n 45) }\end{array}$ & $\begin{array}{l}\text { Кращі команди } \\
\text { Першої ліги } \\
\text { України (n 45) }\end{array}$ & $\mathrm{t}$ & $\mathrm{p}$ \\
\hline $\begin{array}{c}\text { Всього передачі, } \\
\text { к-ть разів }\end{array}$ & $487,9 \pm 30,3$ & $394,0 \pm 22,8$ & 2,20 & $<0,05$ \\
\hline $\begin{array}{c}\text { Передачі вперед, } \\
\text { к-ть разів }\end{array}$ & $145,0 \pm 19,3$ & $141,3 \pm 16,6$ & 0,14 & $>0,05$ \\
\hline $\begin{array}{c}\text { Довгі передачі, } \\
\text { к-ть разів }\end{array}$ & $42,3 \pm 3,6$ & $53,5 \pm 3,7$ & 2,17 & $<0,05$ \\
\hline $\begin{array}{c}\text { Передачі в останню } \\
\text { третину, } \\
\text { к-ть разів }\end{array}$ & $60,9 \pm 4,2$ & $53,5 \pm 3,7$ & 0,48 & $>0,05$ \\
\hline $\begin{array}{c}\text { Передачі в розріз, } \\
\text { к-ть разів }\end{array}$ & $9,2 \pm 0,2$ & $8,3 \pm 0,4$ & 2,01 & $<0,05$ \\
\hline $\begin{array}{c}\text { Темп гри, } \\
\text { передач/хв }\end{array}$ & $16,9 \pm 0,5$ & $16,0 \pm 0,4$ & 1,4 & $>0,05$ \\
\hline
\end{tabular}

У таблиці 3 наведені середні показники виконання передач кращими командами Прем'єр- та Першої ліги України сезону 2020/2021 р.

Порівнюючи кількісні показники виконання передач команд різної кваліфікації, встановлено, що команди Прем'єр-ліги перевищують команди Першої ліги за показниками загальної кількості передач $(\mathrm{t}=2,20 ; \mathrm{p}<0,05)$ та передач в розріз ( $\mathrm{t}=2,01 ; \mathrm{p}<0,05)$. Ці відмінності пояснюються тактичною підготовленістю як команди в цілому, так і майстерністю гравців. Команди вищої кваліфікації більше контролюють м'яч, що зумовлюється збільшенням загальної кількісті передач м'яча під час гри, а передачі в розріз дають можливість зробити атаки значно креативнішими.

Команди Першої ліги мають кращі показники в кількості довгих передач за гру $(t=2,17 ; p<0,05)$, хоча ці результати також підтверджують ствердження, що кращі команди більше контролюють м'яч за рахунок коротких та середніх передач.

\section{Висновки / Дискусія}

Дані проведеного дослідження свідчать про відмінності показників виконання передач кращими ко- мандами Прем'єр- та Першої ліги України сезону 2020/2021 p.

Підтверджено дані (Перевозник В.І., Перцухов А.А.) щодо кількісних показників виконання передач команд високої кваліфікації. Доповнені та розширені дані (Голомазова С.В., Чирва Б.Г., Лисенчука Г.А.), щодо ефективності виконання ключових передач м'яча у футболі.

Результати проведеного дослідження підтвердили дані щодо особливостей використання передач командами різної кваліфікації. Так, в даному дослідженні відзначається, що у команд більш високого рівня кращі показники загальної кількості передач та передач м'яча в розріз, а кількість довгих передач значно нижча. В дослідженнях вперше здійснено порівняльний аналіз передач м'яча кращих команд Прем'єр-ліги та Першої ліги України з футболу. Висновки та основні положення дослідження можуть враховуватися при побудові навчально-тренувального процесу команд різної кваліфікації.

Перспективи подальших досліджень. Подальші дослідження будуть присвячені встановленню особливостей тактичних дій в атаці команд різної кваліфікації.

Конфлікт інтересів. Автори заявляють, що відсутній конфлікт інтересів, який може сприйматись таким, що може завдати шкоди неупередженості статті.

Джерела фінансування. Ця стаття не отримала фінансової підтримки від державної, громадської або комерційної організації. 


\section{Список посилань}

1. Голомазов С. В.,Чирва Б. Г. (2008), Теория и методика футбола. Том 1. Техника игры. М.: ТВТ Дивизион, 476 с.

2. Лісенчук Г. А., Тищенко В. О. (2020), «Технологія контролю техніко-тактичної підготовленості футболістів високої кваліфікації», Наука в олимпийском спорте. № 1. С. 52-56.

3. Мулик В. В., Шаленко В. В., Абдула А. Б., Перцухов А. А. (2015), «Ритм і темп веденнягри команд високоїкваліфікації», Слобожанський науково-спортивний вісник, №3 (47). С. 80-83.

4. Перевозник В. И., Перцухов А. А. (2007), «Исследование передач мяча в одно касание по итогамчемпионата мира 2006 г.», Слобожанський науково-спортивний вісник. №12. С. 81-84.

5. Перцухов А. А., Шаленко В. В. (2017), «Характеристика голевых передач мяча в играх командвысокойквалификации», Науковий часопис Національного педагогічного університету імені М.П. Драгоманова. Серія №15. Науково-педагогічні проблеми фізичної культури / фізична культура і спорт. №3 (84). С. 73-77.

6. Шамардин В.Н.(2002), Моделирование подготовленности квалифицированных футболистов. Днепропетровск: Пороги, 200 с.

7. Bangsbo J. (1998), «The physiological profile of soccer players», Sports Exerciseand Injury, No4, P. 144-150.

8. Bangsbo J., Norregaard L., Thorsoe F. (1991), «Activity profile of competition soccer», J. SportsSci, No16 (2), P. 6-110.

9. Brewel J., Davis J.A. (1992), «A physiological comparison of English professional and semi-professional soccer players», J. Sports Sci, No10, P. 7-146.

10. Haff G. G., Haff E. E. (2012), Training integration and periodization. National Strength and Conditioning Association; ed. By J. Hoffman. Champaing, IL : Human Kinetics, 325 p.

11. Mackenzie R., Cushion C. (2012), «Performance analysis in football: A critical review and implications for future research», Journal of Sports Sciences. vol.31(6), pp. 639-676. doi:10.1080/02640414.2012.746720

Стаття надійшла до редакції: 11.05 .2021 р.

Опубліковано: 23.06.2021 p.

Аннотация. Анатолий Абдула. Особенности выполнения передач мяча лучшими командами Премьер- и Первой лиги Украины по футболу. Цель: определить показатели выполнения передач мяча в футболе команд различной квалификации. Материал и методы: регистрация передач мяча осуществлялась на примере лучших команд Премьер-лиги: «Динамо» Киев, «Шахтер» Донецк, «Заря» Луганск и лидеров Первой лиги Украины: “Верес» Ровно, «Черноморец» Одесса, «Металлист 1925» Харьков сезона 2020/2021 года. Всего было зарегистрировано 90 футбольных матчей. Для решения поставленных задач в работе применялись следующие методы исследования: анализ научно-методической литературы, регистрация передач мяча во время игры, методы математической статистики. Результаты: в статье представлены данные по выполнению передач мяча лучшими командами Премьер- и Первой лиги Украины по футболу. Проведен анализ эффективности общего количества передач мяча, передач вперед, длинных передач, передач в последнюю треть поля, передач в разрез и определялся темп игры каждой из команд. Установлены различия использования передач мяча лучшими командами Премьер-лиги: «Динамо» Киев, «Шахтер» Донецк, «Заря» Луганск и лидеров Первой лиги Украины: «Верес» Ровно, «Черноморец» Одесса, «Металлист 1925» Харьков сезона 2020/2021 г. Выводы: данные исследования свидетельствуют о различиях в использовании передач мяча командами различной квалификации в чемпионате и первенстве Украины по футболу сезона 2020/2021. Так, отмечается, что у команд более высокого уровня лучшие показатели общего количества передач и передач мяча в разрез, а количество длинных передач значительно ниже.

ключевые слова: передачи мяча, тактика, эффективность, темп игры.

Abstract. Anatoliy Abdula. Peculiarities of the ball passing by the best teams of the Premier League and the First League of Ukraine on football. Purpose: to determine the performance of ball passing in football teams of different qualifications. Material and methods: the registration of ball passes was carried out on the example of the best teams of the Premier League: Dynamo Kiev, Shakhtar Donetsk, ZoryaLugansk and the leaders of the First League of Ukraine: VeresRivne, Chornomorets Odessa, Metalist 1925 Kharkiv season 2020/2021. A total of 90 football matches were recorded. To solve the set tasks, the following research methods were used in the work: analysis of scientific and methodological literature, registration of ball passes during the game, methods of mathematical statistics. Results: the article presents data on the performance of ball passes by the best teams of the Premier and the first Ukrainian football league. The analysis of the effectiveness of the total number of ball passes, forward passes, long passes, passes to the last third of the field, cut passes, and the pace of play of each of the teams was determined.The differences in the use of ball passes by the best teams of the Premier League: Dynamo Kiev, Shakhtar Donetsk, ZoryaLugansk and the leaders of the First League of Ukraine: VeresRivne, Chornomorets Odessa, Metalist 1925 Kharkiv season 2020/2021 d. Conclusions: research data indicate the differences in the use of ball passes by teams of different qualifications of Ukraine on football of the 2020/2021 season. Thus, it is noted that teams of a higher level have better indicators of the total number of passes and ball passes, and the number of long passes is much lower.

Keywords: passing the ball, tactics, efficiency, pace of the game.

\section{References}

1. Golomazov, S. V., Chirva, B. G. (2008), Teoriya i metodika futbola. Tom 1. Tehnika igryi. M.: TVT Divizion, 476 p. (in Russ.)

2. Lisenchuk, H. A., Tyshchenko, V. O. (2020), «Technology control of technical and tactical training of highly qualified football players», Nauka v olympyiskom sporte. No. 1. pp. 52-56. (in Ukr.).

3. Mulyk, V. V., Shalenko, V. V., Abdula, A. B., Pertsukhov, A. A. (2015), «Rhythm and pace of the game of highly qualified teams», Slobozhanskyi naukovo-sportyvnyi visnyk, No. 3 (47). pp. 80-83. (in Ukr.). 
4. Perevoznik, V. I., Pertsuhov, A. A. (2007), «2006 World Cup One-Touch Passing Study», Slobozhanskyi naukovo-sportyvnyi visnyk, No.12. pp. 81-84. (in Russ.).

5. Pertsuhov, A. A., Shalenko, V. V. (2017), "Characteristics of assists in the games of teams of high qualifications", Naukovyi chasopys Natsionalnoho pedahohichnoho universytetu imeni M.P. Drahomanova. Seriia №15. Naukovo-pedahohichni problemy fizychnoi kultury / fizychna kultura i sport. No. 3 (84). pp. 73-77. (in Russ.).

6. Shamardin, V. N. (2002), Modelirovanie podgotovlennosti kvalifitsirovannyih futbolistov. Dnepropetrovsk: Porogi, 200 p. (in Russ.).

7. Bangsbo, J. (1998), «The physiological profile of soccer players», Sports Exerciseand Injury, No4, P. 144-150. (in Eng.).

8. Bangsbo, J., Norregaard, L., Thorsoe, F. (1991), «Activity profile of competition soccer», J. SportsSci, No16 (2), P. 6-110. (in Eng.).

9. Brewel, J., Davis, J.A. (1992), «A physiological comparison of English professional and semi-professional soccer players», J. Sports Sci, No10, pp. 7-146. (in Eng.).

10. Haff, G. G., Haff, E. E. (2012), Training integration and periodization. National Strength and Conditioning Association; ed. By J. Hoffman. Champaing, IL : Human Kinetics, 325 p. (in Eng.).

11. Mackenzie, R., Cushion, C. (2012), «Performance analysis in football: A critical review and implications for future research», Journal of Sports Sciences. vol.31(6), pp. 639-676. doi:10.1080/02640414.201 2.746720 (in Eng.).

Received: 11.05.2021.

Published: 23.06.2021.

\section{Відомості про авторів / Information about the Authors}

Абдула Анатолій Борисович: к.фіз.вих., доцент; Харківська державна академія фізичної культури: вул. Клочківська 99, Харків, 61058, Україна.

Абдула Анатолий Борисович: к.физ.восп., доцент; Харьковская государственная академия физической культуры: ул. Клочковская 99, Харьков, 61058, Украина.

Anatoliy Abdula: PhD (Physical Education and Sport), Associate Professor; Kharkiv State Academy of Physical Culture: Klochkivska str. 99, Kharkiv, 61058, Ukraine.

ORCID: http://orcid.org/0000-0002-3832-3716

E-mail: anatoliy.ab12@gmai.com 